\title{
PHYTAL MACROFAUNA COMPOSITION OF THE Himantothallus grandifolius (HETEROKONPHYTA, DESMARESTIACEAE) FROM ADMIRALTY BAY (KING GEORGE ISLAND, SOUTH SHETLAND ISLANDS, ANTARCTICA)
}

http://dx.doi.org/10.4322/apa.2014.081

Tais Maria de Souza Campos ${ }^{1, *}$, Ingrid Avila da Costa ${ }^{2}$, Geyze Magalhães Faria1, Yocie Yoneshigue-Valentin ${ }^{1}$, Adriana Galindo Dalto

'Laboratório de Macroalgas Marinhas, Departamento de Botânica,Instituto de Biologia, Universidade Federal do Rio de Janeiro - UFRJ, Av.Carlos Chagas Filho, 373, bloco A, sala A1-094, Ilha do Fundão,

CEP 21941-902, Rio de Janeiro, RJ, Brazil

*e-mail: tmscampos@yahoo.com.br

Abstract: Phytal ecosystems are characterized as an important area of production and energy transference, due to the complex trophic web that naturally establishes between diverse organism groups that co-inhabit this eutrophic region. Benthic organisms, especially of the macro- and meiobenthic, constitute the associated fauna of the phytal kelps. Himantothallus grandifolius is the most prominent Antarctic kelp species. It is usually found in the Antarctic Peninsula Islands of the Maritime Antarctic region, despite the ecological importance of associated fauna. The present work has the objective to evaluate qualitatively and quantitatively the macrofauna phytal of the H. grandifolius collected in February 2011 at Mackelar inlet (Admiralty Bay), with special focus on taxonomic determination of the associated Isopods fauna. Preliminary results showed that the dominant faunal group was Amphipods ( $n=1776)$, followed by Ectoprocta $(n=496)$. Isopods occurred in fewer density $(n=207$ ind.) and so far have been identified at the following family level (Gnathiidae, Munnidae, Plakarthidae, Jaeropsidae, Sphaeromathidae and Janiridae).

Keywords: Kelps, Himantothallus grandifolius, phytal fauna, Isopods

\section{Introduction}

The seaweed and seagrass communities have a great importance in the development of invertebrate and vertebrate communities, creating favorable conditions of habitat, shelter, feeding, reproduction and development for the life cycles of various marine organisms. The marine biocenosis constituted by animals that live associated to these plant-substrates is designated phytal (Masunari \& Forneris, 1981; Remane, 1933; Masunari, 1987). Phytal communities are mainly composed by invertebrates of the macrofauna ( 0.5 to $2 \mathrm{~mm}$ ) and meiofauna ( 0.045 to $0.5 \mathrm{~mm}$ ) size classes. In Admiralty Bay Antarctica, especially in, phytal communities are very little studied (Pabis \& Sincinski,
2010; Sicinski et al., 2011). Over all, in Admiralty Bay there are some 36 macroalgae species (Zielinski, 1990) and the Desmarestiaceae is the most common family. From the 36 species Himantothallus grandifolius is the most common kelp in the whole Bay. $H$. grandifolius a Heterokontophyta algae constituted by leaf-like thallus with corrugate edges narrowing downwards forming a short stipe, which can reach a large size both in width, more than $1 \mathrm{~m}$, and depth of between $5-15 \mathrm{~m}$ in total length. This kelp is found attached to rocks and stones by a great number of appendages forming a strong holdfast. Thallus and holdfast of these large brown algae are considered to be structurally complex habitats 
(Steneck et al., 2002), consisting in a rich aggregation in a sublittoral zone ranging within a depth of 10 to $90 \mathrm{~m}$ (Zielinski, 1990).

Phytal fauna of the Admiralty Bay is often composed of Amphipods, Isopods, Polychaetes, bryozoans and ascidians like the phytal in other places of the world (Mukai, 1971; Kito, 1975; Hicks, 1977; Coull \& Wells, 1983; Johnson \& Scheibling, 1987; Preston \& Moore, 1988; Curvêlo \& Corbisier, 2000; Krzysztof \& Sicinski, 2010). There are few studies on Antarctic macroalgae phytal communities, despite their great importance in marine coastal ecosystems. The aim of the present study was to describe phytal macrofauna composition associated to $H$. grandifolius in Admiralty Bay, emphasizing Isopod fauna composition.

\section{Materials and Methods}

Admiralty Bay is located in the King George Island in the central region of South Shetlands Archipelago (Rakusa-Suszczewski, 1980) $62^{\circ} 05^{\prime \prime} \mathrm{S}$ and $58^{\circ} 24^{\prime \prime} \mathrm{W}$. The bay covers some $122.08 \mathrm{~km}^{2}$ (Battke, 1990) and is comprised of three inlets, Martel, Mackelar and Ezcurra. It is the largest bay of King George Island, and about $30 \%$ of the bottom of Admiralty Bay is covered by macroalgae. The specimen of Himantothallus grandifolius was collected in Mackelar inlet near Peruvian Station of Machu Pichu up at 15 meters deep in February 2011. The specimen measured approximately $8 \mathrm{~m}$ long and $60 \mathrm{~cm}$ wide. The holdfast was circular and the diameter was approximately $45 \mathrm{~cm}$. After collecting this specimen, it was stored and frozen immediately. In Brazil, the specimen was thawed (defrosted) at room temperature $\left(25^{\circ} \mathrm{C}\right)$ in Macroalgae laboratory (Biology Institute/UFRJ). During thawing, the organisms associated to seaweed were carefully collected and immediately fixed in neutralizing formaldehyde $4 \%$. The holdfast was washed to remove the sediment and organisms. The sediment was elutriated and the supernatant was poured on two sieves with meshes of 0.500 and $0.045 \mathrm{~mm}$ to separate the macrofauna and meiofauna organisms. Macrofauna organisms were sorted into higher taxonomic levels (Phylum, Class, Order, and others). The Isopods were separated for preliminarily taxonomic identification to Family level and expressed in number of individuals found across the seaweed thallus and holdfast.
Table 1. Composition and density ( $n^{\circ}$.ind.) of phytal macrofauna organisms found on Himantothallus grandifolius.

\begin{tabular}{|c|c|c|}
\hline Taxon & Holdfast region & Tallus region \\
\hline Acari & 2 & 0 \\
\hline Amphipoda & 1767 & 116 \\
\hline Asteroidea & 3 & 2 \\
\hline Bivalvia & 33 & 3 \\
\hline Copepoda & 181 & 0 \\
\hline Cumacea & 1 & 0 \\
\hline Gastropoda & 71 & 7 \\
\hline Holoturoidea & 2 & 0 \\
\hline Nematoda & 281 & 0 \\
\hline Nemertea & 3 & 0 \\
\hline Ofiuroidea & 3 & 5 \\
\hline Oligochaeta & 7 & 0 \\
\hline Ostracoda & 20 & 0 \\
\hline Polyplacophora & 19 & 4 \\
\hline Polychaeta & 158 & 9 \\
\hline Ectoprocta & 472 & 32 \\
\hline Gnathiidae* & 71 & 0 \\
\hline Sphaeromatidae* & 1 & 0 \\
\hline Plakarthriidae* & 74 & 0 \\
\hline Munnidae* & 41 & 0 \\
\hline Janiridae* & 3 & 0 \\
\hline Jaeropsidae* & 2 & 0 \\
\hline Total & 3215 & 178 \\
\hline $\begin{array}{l}\text { Total Holdfast } \\
\text { and tallus }\end{array}$ & \multicolumn{2}{|c|}{3393} \\
\hline
\end{tabular}

* Isopod Families

\section{Results}

The preliminarily results showed that phytal fauna of Himantothallus grandifolius were composed by a diversity of organisms: Acari, Crustacea, Mollusca, Echinodermata, Nematoda, Nemertea, Annelida and Ectoprocta (Table 1). Amphipod was the dominant group ( $\mathrm{n}=1776$ ind), followed by Ectoprocta ( $\mathrm{n}=496 \mathrm{ind})$. Isopod found in fewer individuals ( $\mathrm{n}=207$ ind) and the families were Gnathiidae, 


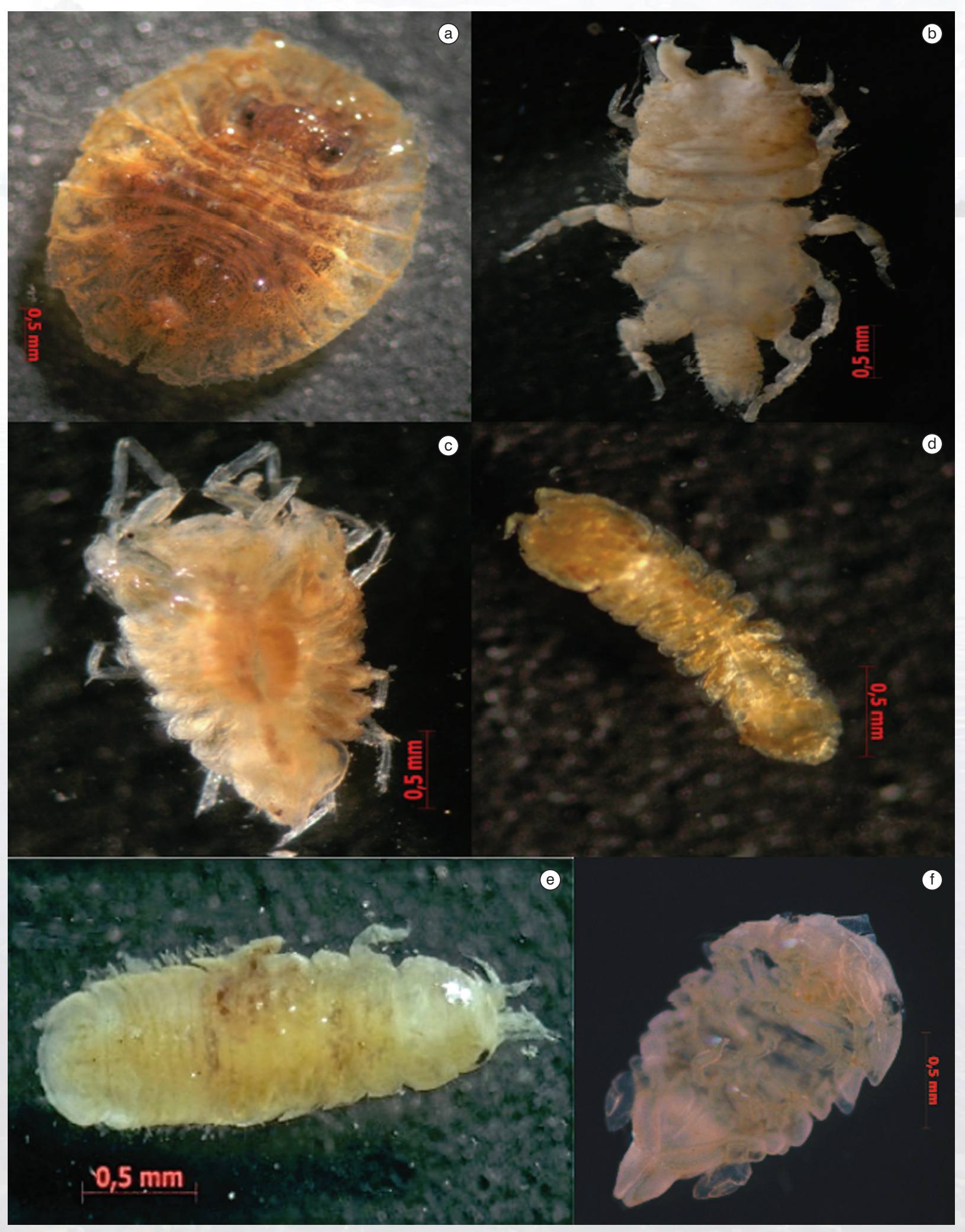

Figure 1. Isopods families associated to Himantothallus grandifolius sampled in Admiralty Bay (King George Island, Antarctica). a) Plakarthriidae; b) Gnathiidae; c) Munnidae; d) Janiridae; e) Jaeropsidae; and f) Sphaeromathidae. 
Munnidae, Plakarthidae, Jaeropsidae, Sphaeromathidae and Janiridae (Figure 1).

The holdfast was the thallus region with the greater diversity. There are a relatively small number of studies focused on the fauna of Antarctic and Subantarctic macroinvertebrates associated with holdfasts of various macroalgae (Arnaud, 1974).

\section{Discussion}

Frequently, the dominant groups of the phytal fauna are Peracarids Crustacea, especially Amphipods, Isopods, Tanaidaceans (Mukai, 1971; Kito, 1975; Hicks, 1977; Coull \& Wells, 1983; Johnson \& Scheibling, 1987; Preston \& Moore, 1988; Curvêlo \& Corbisier, 2000), similar with the faunal composition observed in the present work. Through the taxonomic identification it has been possible from the results obtained so far to suggest that holdfast was the region with the greatest diversity of organisms. The latter can be explained by the morphological aspects of the holdfast such as textures and interstitial spaces that accumulate sediment, debris and epiphytes, in addition to providing a greater degree of protection from as wave exposure and predators (Muralikrishnamurty, 1983; Preston \& Moore, 1988).

The Antarctic marine environment is very peculiar, and presents features like extremely low and stable seawater temperature, $4{ }^{\circ} \mathrm{C}$ a $-70{ }^{\circ} \mathrm{C}$, marked differences in the incidence of light throughout the year, small fluctuations in salinity during the summer and a marked seasonality in food resource input in relation to the annual cycle of primary productivity (Gutt, 2007). In this environment, large macroalgae (Kelps) modify physical factors such as light or water movement and can play a fundamental role on the distribution patterns and diversity of the marine organisms (Reed \& Foster 1984, Bulleri et al., 2002).

\section{Acknowledgements}

This work integrates the National Institute of Science and Technology Antarctic Environmental Research (INCTAPA) that receive scientific and financial supports of the National Council for Research and Development (CNPq process: $n^{\circ}$ 574018/2008-5) and Research Support Foundation of the State of Rio de Janeiro (FAPERJ $n^{\circ}$ E-16/170.023/2008). The authors also acknowledge the support of the Brazilian Ministries of Science, Technology and Innovation (MCTI), of Environment (MMA) and Inter-Ministry Commission for Sea Resources (CIRM). The authors also acknowledge the research fellows for Scientific Initiation (Tais Maria de Souza Campos, - CNPq 110657/2011-0) and Post-doctoral (Adriana Galindo Dalto CAPES/FAPERJ E-26/102.016/2009).

\section{References}

Arnaud, P.M (1974). Contribution a la bionomie marine benthique des regions antarctiques et subantarctiques. Tethys, 6: $465-656$

Battke, Z. (1990). Admiralty Bay, King George Island, Map, 1 :50.000. Nackladem Instytutu Ekologii, Polish Academy of Science.

Bulleri, F.; Bertocci, I. \& Micheli, F. (2002). Interplay of encrusting coralline algae and sea urchins in maintaining alternative habitats. Marine Ecology Progress Series, 243: 101-109.

Coull, B.C. \& Wells, J.B.J. (1983). Refuges from fish predation: experiments with phytal meiofauna from the New Zealand roccky intertidal. Ecology, 64: 1599-1609.

Curvêlo, R.R. \& Corbisier, T.N. (2000). The meiofauna associated with Sargassum cymosum at Lázaro beach, Ubatuba, São Paulo. Revista Brasileira de Oceanografia, 48(2): 119-130

Gutt, J. (2007). Antarctic macro-zoobenthic communities: a review and an ecological classification. Antarctic Science, 19 (2): 165-182.

Hicks, G.R.F. (1977). Observations on substrate preference of marine phytal Harpacticoids (Copepoda). Hydrobiologia, 56(1): 7-9

Johnson, S.C. \& Scheibling, R.E. (1987). Structure and dynamics of epifaunal assemblages on intertidal macroalgae Ascophyllum nodosum and Fucus vesiculosus in Nova Scotia, Canada. Marine Ecology Progress Series, 37: $209-227$. 
Kito, K. (1975). Preliminary report on the phytal animals in the Sargassum confusum region in Oshoro Bay, Hokkaido. Journal of the Faculty of Science, Hokkaido University. Series 6, Zoology, 20(1): 141-158.

Krzysztof, P. \& Sicinski, J. (2012). Polychaete fauna associated with holdfasts of the large brown alga Himantothallus grandifolius in Admiralty Bay, King George Island, Antarctic. Polar Biology, 33: 1277-1288.

Masunari, S. \& Forneris, L. (1981). O Ecossistema Fital - Uma Revisão. Seminários de Biologia Marinha, Academia Brasileira de Ciências, Rio de Janeiro. p. 149-172.

Masunari, S. (1987). Ecologia das Comunidades Fitais. Academia de Ciências do Estado de São Paulo. Simpósio sobre ecossistemas da costa sul e sudeste Brasileira. 459 p.

Mukai, H. (1971). The phytal animals on the thalli of Sargassum serratifolium in Sargassum sp. Region, with reference to their seasonal fluctuations. Marine Biology, 8: 170-182.

Muralikrishnamurty, P.V. (1983). Intertidal phytal fauna of Gangavaram, east coast of India. Indian Journal of Marine Sciences, 2(2): 85-89.

Pabis, K. \& Siciski, J. (2010). Distribution and diversity of polychaetes collected by trawling in Admiralty Bay-and Antarctic glacial fiord. Polar Biology, 33: 141-151.

Preston, A. \& Moore, P.G. (1988). The flora and fauna associated with Cladophora albida Kutz. From rockpools on Great Gambrae Island, Scotland. Ophelia, 29: 169-186.

Rakusa-Suszczewski, S. (1980). Environmental conditions and the functioning of Admiralty Bay (South Shetland Islands) as a part of the near shore Antarctic ecosystem. Polish Polar Research, 1: 11-27.

Reed, D.C. \& Foster, M.S. (1984). The effects of canopy shading on algal recruitment and growth in a giant kelp forest. Ecology, 65(3): 937-948.

Remane, A. (1933) Verteilung und Organization der Benthonischen in Mikrofauna in der Kieler Bucht. Wiss Meeresunters, Abt Kiel, 21: 163-221.

Steneck, R.S.; Graham, M.H.; Bourque, B.J.; Corbett, D.; Erlandson, J.M.; Estes, J.A. \& Tegner, M.J. (2002). Kelp forest ecosystems: biodiversity, stability, resilience and future. Environmental Conservation, 29: 436-59.

Sicinski, J.; Krzysztof, J.; De Broyer, C.; Piotr, P.; Ryszard, L.; Nonato, E.F.; Corbisier,T.N.; Brito,T.A.S.; Lavrado, H.P.; BazewiczPaszkowycz, M.; Krzysztof, P. Jaz 'dz' ewska, A. \& Campos, L.S. (2011). Admiralty Bay Benthos Diversity A census of a complex polar ecosystem. Deep-Sea Research II, 58: 30-48.

Zielinski, K. (1990). Bottom macroalgae of the Admiralty Bay King George Island, South Shetlands, Antarctica. Polish Polar Research, 11 (12): 95-131.

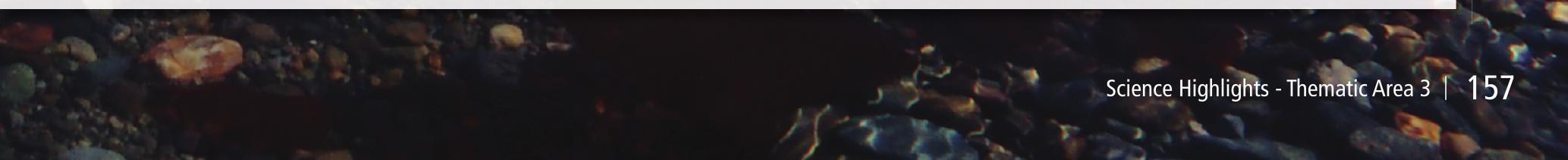

